\title{
Traumatic experiences and re-victimization of female inmates undergoing treatment for substance abuse
}

\author{
Bertha Mejía', Paloma Zea ${ }^{1}$, Martha Romero ${ }^{2 *}$ and Gabriela Saldívar ${ }^{2}$
}

\begin{abstract}
Background: In the past decade, several studies have focused on the treatment needs of female inmates with substance abuse problems. An important finding has been that these women are more likely to report histories of sexual, physical, and emotional abuse-at rates varying from $77 \%$ to $90 \%$. The trauma resulting from this kind of abuse is a key contributing factor in behavioral problems in adolescence and subsequent delinquency, substance abuse, and criminality in adulthood.
\end{abstract}

Methods: This was a retrospective clinical study. A convenience sample of 112 women who entered the program's treatment groups consecutively for one year form part of the study. Information on traumatic events was obtained using some questions from the Initial Trauma Review. It explores whether the participant experienced physical abuse, sexual abuse, disasters, automobile accidents, or witnessed violence under the age of 18. It also examines experiences as an adult, including sexual and physical abuse, attacks by others who are not intimate partners, and abuse by authorities.

Results: Revictimization in sexual abuse was found in $78.1 \%$ of participants. Significant differences were identified between women who had experienced a traumatic sexual event from a person five years their senior before the age of 18 and then suffered from sexual violence as an adult, and women who had never undergone either of these events $\left(x^{2}=11.3\right.$, df $\left.112 / 1, p=<.001\right)$. In physical abuse, the figure was $82.17 \%$. Differences were observed between women who were revictimized through physical abuse before and after the age of $18\left(x^{2}=5.91, \mathrm{df} 112 / 1\right.$, $p=<.01$ ), and those who had not experienced any kind of revictimization. Significant differences were found between women who had suffered a traumatic sexual event as a child and subsequently physical violence from their parents, and women who had not undergone either of these events $\left(x^{2}=3.48\right.$, df $\left.112 / 1, p=<.05\right)$.

Conclusions: Investment in treatment in these areas during the prison sentence and after release may contribute to preventing these women from become repeat offenders. Creating sources of work and halfway houses that continue the program to prevent relapses into substance use can help defend the human rights of this group of women and achieve social justice.

Keywords: Women, Prison, Substance abuse, Traumatic experiences

\footnotetext{
* Correspondence: martha.promero2@gmail.com

${ }^{2}$ Instituto Nacional de Psiquiatría Ramón de la Fuente Muñiz, Camino a

Xochimilco 101. San Lorenzo Huipulco, Tlalpan 14370, D. F, México

Full list of author information is available at the end of the article
} 


\section{Background}

In the past decade, several studies have focused on the treatment needs of female inmates with substance abuse problems. An important finding has been that these women are more likely to report histories of sexual, physical, and emotional abuse-at rates varying from $77 \%$ to $90 \%$. The trauma resulting from this kind of abuse is a key contributing factor in behavioral problems in adolescence and subsequent delinquency, substance abuse, and criminality in adulthood. Moreover, surveys of female inmates have consistently shown a strong link between childhood abuse and mental health problems in adulthood, particularly depression, post-traumatic stress, panic attacks, and eating disorders. The costs of failure to diagnose and treat psychiatric disorders in female criminals are high and may lead to other problems, including unemployment, homelessness, and losing custody of children [1-5].

Research has also shown that female inmates with psychoactive substance dependence are more likely to have chronic health problems, including hepatitis, toxemia, anemia, hypertension, diabetes, and obesity [6]. They also have a greater risk than men of having HIV/AIDS on admission to prison, due to their greater participation in prostitution.

Trauma has been defined as a form of damage to a person that occurs as a result of a severely distressing experience. According to SAHMSA [7], individual trauma results from an event, series of events or set of circumstances experienced by an individual as physically or emotionally harmful or threatening, which has lasting adverse effects on the individual's functioning and physical, social, emotional or spiritual well-being. According to WHO [8], traumatic events and loss are common in people's lives.

In a study conducted by the World Health Organization, over $10 \%$ of respondents reported witnessing violence (21.8\%) or experiencing interpersonal violence $(18.8 \%)$, accidents $(17.7 \%)$, exposure to war $(16.2 \%)$ or a trauma suffered by a loved one (12.5\%). An estimated $3.6 \%$ of the world population has suffered from posttraumatic stress disorder (PTSD) in the previous year [9]. Violence and trauma, however, have far-reaching effects on the wellbeing of their victims, particularly in relation to drug use.

The links between physical and sexual abuse, mental illness, and substance abuse are complex, multifaceted, and multidirectional [10]. According to Wilson [11], the experience of women who have been sexually abused in childhood is expressed in several ways: a) behavior, such as dysfunctional relationships, aggression, hostility, substance abuse, and promiscuity; b) emotions, such as fear, anxiety, anger, depression, and hyper vigilance; c) systemic disorders that translate into respiratory, gastrointestinal, neurological, and gynecological problems; and d) pain, including headaches, back pain, and pelvic pain, coupled with the abuse of analgesics. Sexual abuse also leads to the development of consequences of posttraumatic stress, such as insomnia, memory loss, fatigue, and autoimmune disease [12,13].

An experience of physical, sexual, or emotional abuse may increase the risk of developing mental health problems. In turn, these problems together with substance abuse put women at greater risk of suffering this type of abuse. Lastly, excess consumption and other selfdestructive behavior may be the result of traumatic experiences [14]. In other words, there is evidence that the relationship is bidirectional. Sexual abuse generally precedes first alcohol use, although trauma survivors report abuse both before and after. At the same time, childhood sexual abuse is associated with greater substance abuse, which may be linked to an increased risk of revictimization [15].

Whereas victimization is conceived of as receiving violence (physical, sexual or emotional), revictimization is defined as being the victim of interpersonal violence on two or three occasions, carried out by at least two difference perpetrators. More specifically, it refers to undergoing physical or sexual abuse by a family member during childhood, then experiencing it again as an adult, when the perpetrator is the male partner [16].

According to Matthews [17] in a work proposal to reform Latin American prisons, the close relationship between drug use and committing crimes is one of the main problems faced by correctional facilities. Imprisonment can even create or exacerbate drug addiction. In a study on Mexican prisons, Bergman and Azaola [18] report that the prison authorities estimate that $50 \%$ of the population regularly consume drugs.

Despite of the previous data, Mexico City's jails (the Centros de Readaptación Social, or CERESOs) have no publicly-funded treatment programs for substance abuse, and there is little available scientific research on the needs of their female inmates [19]. The Monte Fénix Foundation has developed the Recovery from Addiction to Psychoactive Substances Program at the women's CERESO at Santa Martha Acatitla, and covers the full cost of the program. Its objective is to provide a response to this health problem with a program specifically designed for the female population. It grants women access to professional treatment, providing them with information and tools, allowing them to begin a recovery process that leads to a better quality of life.

Among the research questions behind the study were: What are the characteristics of addictive substance use in women? What kind of traumatic experiences have they suffered? Have they experienced revictimization?

The objective of the present study is to describe the traumatic events and revictimization suffered being 
children and later being adults by the population that entered treatment for abuse of psychoactive substances. Besides, provides recommendations for optimizing their substance abuse and violence treatment.

\section{Methods}

This was a retrospective clinical study. The research project was approved by the Ethics and Research Committee at the Monte Fénix Higher Education Center. In view of the fact that women in prison are a vulnerable group, each woman signed an informed consent form that explained the objectives of the project and of their participation. Moreover, the form clearly stated that there was no risk involved, and that it was a voluntary process that ensured anonymity and confidentiality. To guarantee that there was no coercion, each woman signed her consent form in the presence of two witnesses of their choice, and was informed that if at any moment she decided to drop out of the project, there would be no repercussions on her treatment.

The free treatment model is implemented inside the prison and has the capacity to provide 30 places for each group of women wishing to take part voluntarily. These participants spend 90 days isolated from the rest of the prison population. Thus, every three months a group of 30 women is admitted to these facilities.

A convenience sample of 112 women who entered the program's treatment groups consecutively for one year form part of the study.

\section{Treatment}

The program uses a facility inside the prison, provided by the CERESO authorities so the participants can be isolated from the rest of the population. The treatment unit was created inside a section of a CERESO and comprises 13 cells. Each of the cells has four beds, a bathroom and a laundry room. The dining area is a space adapted in the corridor, with tables and chairs. It is important to mention that in Mexico there are no mixed gender prison settings.

It has a staff of five therapists and one physician with experience in the treatment of addiction problems, with three additional professionals assigned to provide continuity, who are trained at the Monte Fénix Higher Education Center, at the Clínica de Atención Integral en Desintoxicación y Recuperación (CLAIDER), and on site.

As each woman is admitted, she undergoes a medical clinical assessment in the presence of a nurse. Laboratory tests with 28 elements are taken. The women undergo a pharmacological detoxification process that uses neuroprotective agents. All women with a non-psychotic psychiatric disorder for which they take medicine will continue to take it, in consultation with a psychiatrist.
The program is based on six fundamental concepts:

1. Abstinence: The Path to Recovery

2. Medical Treatment

3. Psychotherapeutic Treatment

4. Education and Information

5. Twelve-step Program of Alcoholics Anonymous

6. Continuous Treatment

Between May 2006 and April 2013, 789 women voluntarily entered the treatment center.

Women were invited to register for a detoxification program located inside the prison. After giving their written informed consent to enter treatment, they signed a written agreement outlining the rules of participation in the program, and lastly an informed consent form, with two witnesses, to allow their information to be used for research purposes.

\section{Table 1 Demographics}

\begin{tabular}{|c|c|c|}
\hline & $\mathrm{N}$ & $\%$ \\
\hline \multicolumn{3}{|l|}{ Civil status } \\
\hline Married & 16 & 43.0 \\
\hline Living together & 33 & 29.5 \\
\hline Widowed & 5 & 4.5 \\
\hline Divorced & 1 & 0.9 \\
\hline Separated & 20 & 17.9 \\
\hline Never married/single & 37 & 33.0 \\
\hline \multicolumn{3}{|l|}{ Number of children } \\
\hline 0 & 10 & 9.9 \\
\hline $1-3$ & 68 & 67.3 \\
\hline $4-6$ & 23 & 22.8 \\
\hline \multicolumn{3}{|l|}{ Sexual preference } \\
\hline Heterosexual & 60 & 53.6 \\
\hline Homosexual (gay/lesbian) & 12 & 10.7 \\
\hline Bisexual & 39 & 34.8 \\
\hline Other & 1 & 0.9 \\
\hline \multicolumn{3}{|c|}{ Lived with both biological parents before 18 years } \\
\hline Yes & 66 & 58.9 \\
\hline No & 46 & 41.1 \\
\hline \multicolumn{3}{|c|}{ Who raised you before 18 years } \\
\hline Both biological parents & 31 & 27.7 \\
\hline Only biological mother & 40 & 35.7 \\
\hline Only biological father & 6 & 5.4 \\
\hline Grandparents & 24 & 21.4 \\
\hline Other relatives & 4 & 3.6 \\
\hline Institution or orphanage & 1 & 0.9 \\
\hline Other & 6 & 5.4 \\
\hline
\end{tabular}


Table 2 Lifetime drug use

\begin{tabular}{lllllll}
\hline & Yes & & & No & & \multicolumn{1}{c}{$\begin{array}{c}\text { Age of onset } \\
\text { (Media and deviation) }\end{array}$} \\
\cline { 2 - 3 } & $\mathbf{N}$ & $\%$ & & $\mathbf{n}$ & $\%$ & \\
\hline Alcohol & 109 & $(97.3)$ & 3 & $(2.7)$ & $14.90(5.61)$ \\
Tobacco & 110 & $(98.2)$ & 2 & $(1.8)$ & $14.99(5.90)$ \\
Marihuana & 101 & $(89.3)$ & 11 & $(10.7)$ & $20.16(8.32)$ \\
Cocaine & 95 & $(83.9)$ & 17 & $(16.1)$ & $24.13(32.07)$ \\
Heroin & 9 & $(7.2)$ & 103 & $(92.8)$ & $17.89(9.04)$ \\
Hallucinogens & 20 & $(18.9)$ & 92 & $(81.1)$ & $17.75(5.57)$ \\
Inhalants & 63 & $(57.1)$ & 49 & $(42.9)$ & $17.08(6.60)$ \\
Amphetamines & 22 & $(19.3)$ & 90 & $(80.7)$ & $20.77(7.67)$ \\
Opiates & 2 & $(0.9)$ & 110 & $(99.1)$ & $22.50(3.53)$ \\
Tranquilizers & 54 & $(49.5)$ & 58 & $(50.5)$ & $21.00(6.06)$ \\
Sedatives & 5 & $(4.8)$ & 107 & $(95.2)$ & $21.40(6.58)$ \\
Stimulants & 4 & $(3.7)$ & 108 & $(96.3)$ & $21.25(9.50)$ \\
Other drugs & 11 & $(15.9)$ & 101 & $(84.1)$ & $20.0(9.06)$ \\
\hline
\end{tabular}

Treatment takes place outside the general population area, inside the prison and lasted three months. It continues after their return to the prison routine with a relapse prevention program. Participants were subsequently evaluated for follow-up at three and six months, with a urine drug test during the second evaluation. Each treatment group included approximately 30 women. Participants were allowed to leave the group if they wished. Those who did not follow the rules were eliminated. Treatment takes place inside the prison, where psychoactive substances and occasionally alcohol, are available.

\section{Instrument}

To obtain a profile of the participant group on entering treatment, the women were given face-to-face interviews given their literacy skills, using a participant data form. Interviews were conducted by clinical specialists in addiction. The data form included eight sections:
1) Demographic section: age, date of birth, ethnicity, place of birth, length of residence at home.

2) Family and marital history: whether the participant had lived with her biological parents prior to the age of 18 , who she was raised by, death of parents, number of biological siblings, sexual orientation, marital status, number of marriages, and number of children.

3) Education and work history: educational attainment and age at which they completed their education, occupation, employment, income, economic dependents.

4) Legal history: arrests, age at first and most recent arrest, months in prison, drug-related crimes, violent crimes, property crimes, public order crimes, other crimes. Criminal activity before and after 18 .

5) Psychiatric and medical history: number of times hospitalized for medical and psychiatric problems and age at hospitalization; disorders, age of onset, and medication.

6) Substance abuse

6) A. History of alcohol use

6) B. History of drug use

6) C. Alcohol and drug treatment

6) D. Family history of alcohol and drug problems

7) Traumatic events: Information on traumatic events was obtained using some questions from the Initial Trauma Review, a semi-structured interview that enables the clinician to evaluate the principal forms of exposure to trauma. It explores whether the participant experienced physical abuse, sexual abuse, disasters, automobile accidents, or witnessed violence under the age of 18 . It also examines experiences as an adult, including sexual and physical abuse, attacks by others who are not intimate partners, and abuse by authorities [20].

8) Legal situation: length of sentence links between sentence and alcohol or drug use, legal advice, previous imprisonment, age at first imprisonment, family history of legal problems.

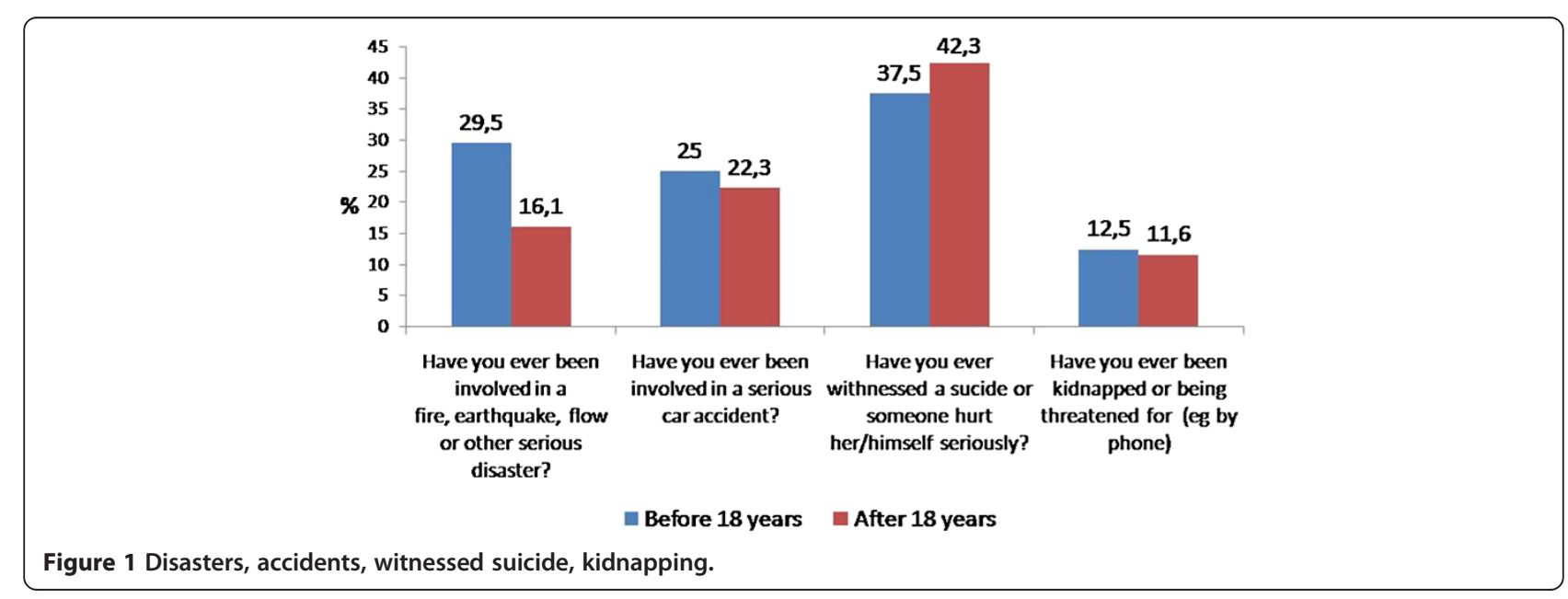




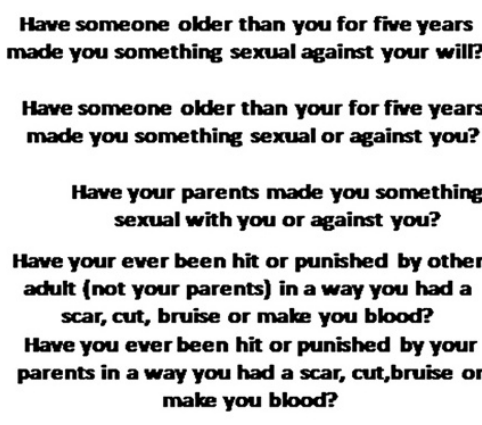

Figure 2 Physical and sexual abuse before 18 years.

The questions used have been validated in Mexican studies, particularly those examining sexual abuse before and after the age of 18 [21].

\section{Results}

A total of 132 women participated in four treatment groups. In the course of the treatment program, 49 women dropped out of the program for a variety of reasons: $12.2 \%$ left voluntarily, $16.6 \%$ were removed for violation of the rules, $3.03 \%$ were released from prison, and $3.7 \%$ were transferred to another facility. The study was carried out on the 112 women who provided complete information in the initial interview. Their sociodemographic characteristics are given in Table 1.

In addition to the characteristics displayed in the tables, $34.8 \%$ of the women stated that they suffered from a chronic medical problem. Among the most frequent were those linked to the digestive system (gastroenteritis, hepatitis, cirrhosis, colitis, diabetes), reported by 14 women (17.8\%) and gynecological problems (human papilloma virus, myomas and infections) and reported by seven women $(8.9 \%)$. Only two women $(2.6 \%)$ reported that they took psychiatric medicine.

The criminal offenses for which they were imprisoned were mainly various kinds of theft $(65.8 \%)$, in addition to murder (7.1\%); crimes against public health (5.6\%); kidnapping (7.4\%); extortion, child abduction, murder of a relative, and other crimes (11.4\%) together with a smaller number of crimes involving forgery and organized crime and kidnapping (1.8\%). Table 2 shows substance use and average age of initial use. After alcohol and tobacco consumption, the most frequently used drugs were marijuana, cocaine, and inhalants.

Figure 1 shows the percentage of women who experienced trauma such as disasters, serious automobile accidents, witnessing suicides, or kidnapping threats. It should be noted that the last two were common experiences being adults. Of particular interest are the high percentage of those who experienced trauma before the age of 18 and those who witnessed a suicide after that age.

Figure 2 shows physical and sexual abuse experienced prior to the age of 18 .

Figure 3 shows adult physical and sexual abuse.

Due to the fact that a single woman may have suffered several traumatic events, it was decided that both the distribution and an average of these would be calculated. Figure 4 shows the distribution of traumatic events in the study group, with a range of 1-13 events and a mean of 6 .

To undertake an analysis of the link between demographic variables and the number of lifetime traumas, women were divided into two groups: one group with

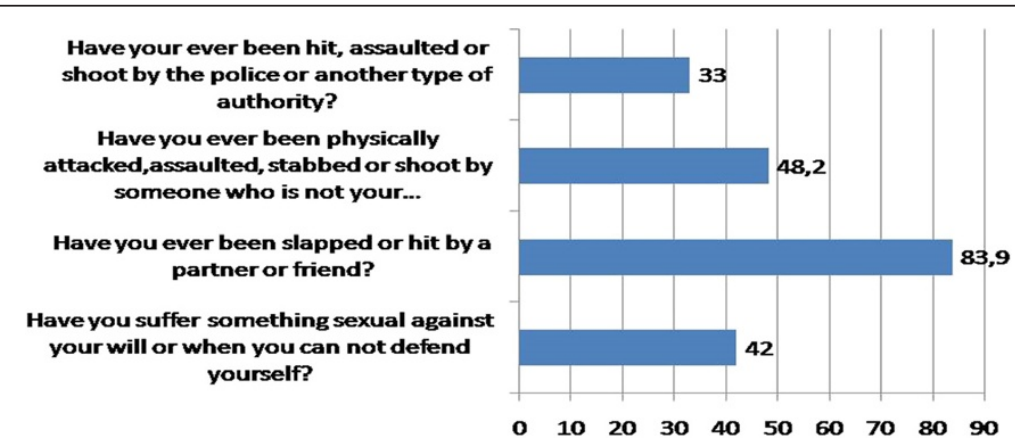

Figure 3 Adult physical and sexual abuse $\mathrm{N}=112$. 


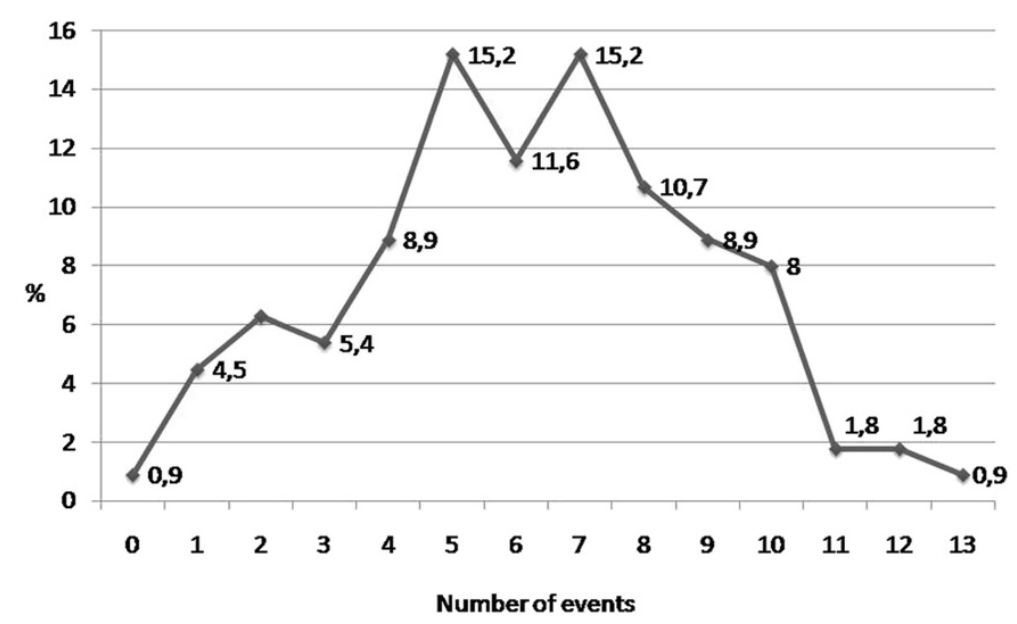

Figure 4 Traumatic events distributions. $N=112, \bar{X}=6.2$.

0-6 traumatic events and another with 7 or more. The variables analyzed were marital status, sexual orientation, death of parents under the age of 18 , who the participant was raised by, whether her parents were divorced, and whether she had lived with both parents at some time under the age of 18 . Only the last of these variables proved significant. Women who had lived with their biological parents constituted a greater proportion of the group with 0-6 traumatic events $\left(\mathrm{x}^{2}=5.7, \mathrm{df}=1\right.$, $\mathrm{p}<.01$ ); in other words, those who had lived with their families experienced fewer such events.

To analyze revictimization in sexual and physical abuse, without regard to the identity of the perpetrator, variables were crossed while being child and like an adult. Revictimization in sexual abuse was found in $78.1 \%$ of participants (Table 3). Significant differences were identified between women who had experienced a traumatic sexual event from a person five years their senior before the age of 18 and then suffered from sexual violence as an adult, and women who had never undergone either of these events $\left(x^{2}=11.3\right.$, df $112 / 1$, $\mathrm{p}=<.001)$.

In physical abuse, the figure was $82.17 \%$. Considerable differences were observed between women who were revictimized through physical abuse before and after the age of $18\left(\mathrm{x}^{2}=5.91, \mathrm{df} 112 / 1, \mathrm{p}=<.01\right)$, and those who had not experienced any kind of revictimization (Table 4).

Table 3 Sexual abuse revictimization

\begin{tabular}{lll}
\hline Sexual abuse & Yes adult & No adult \\
\hline YES childhood & $37(78.7 \%)^{* *}$ & $31(47.7 \%)$ \\
NO childhood & $10(21.3 \%)$ & $34(52.3 \%)$ \\
& $47(100 \%)$ & $65(100 \%)$ \\
\hline
\end{tabular}

$* *\left(x^{2}=11.2, g l 112 / 1, p=<.001\right)$.
Given that a woman may experience both physical and sexual abuse during childhood (before the age of 18), variables were crossed: Before you were 18, did either of your parents hit you or punish you in a way that left a bruise, cut or scar, or made you bleed? With the variable, Has a person at least five years older than you done anything sexual with or towards you? Significant differences were found between women who had suffered a traumatic sexual event as a child and subsequently physical violence from their parents, and women who had not undergone either of these events $\left(x^{2}=3.48\right.$, df $112 / 1$, $\mathrm{p}=<.05)$ (Table 5).

A logistic regression analysis was not possible, as the study sample is extremely homogenous. Neither were notable differences found between revictimization and the use of specific psychoactive substances.

An analysis of the cases in which follow-up revealed a positive drug test compared with negative tests showed no significant differences in the violent events reported.

\section{Discussion}

There is no doubt that the women who participated in this study are a population that has experienced multiple traumas. Messman-Moore, Walsh, and DiLillo [22] define revictimization as an elaboration of the psychological impact of previous victimization. It is associated with increased illness, including high anxiety levels, current and lifelong depression, heavy drinking, and past

Table 4 Physical abuse revictimization

\begin{tabular}{lll}
\hline Physical abuse & Yes adult & No adult \\
\hline Yes childhood & $83(82.17 \%)^{*}$ & $5(45 \%)$ \\
No childhood & $18(17.83 \%)$ & $6(54 \%)$ \\
& $101(100 \%)$ & $11(100 \%)$ \\
${ }^{*} \mathrm{x}^{2}=5.91$, df $112 / 1, \mathrm{p}=<.001$. &
\end{tabular}


Table 5 Traumatic physical and sexual events in childhood

\begin{tabular}{lll}
\hline $\begin{array}{l}\text { Before 18. Have you ever been hit } \\
\text { or punished by your parents in a } \\
\text { way you had a scar, cut, bruise or } \\
\text { make you blood? }\end{array}$ & $\begin{array}{l}\text { Before 18. Have someone older } \\
\text { than you for five years or more } \\
\text { made you something sexual } \\
\text { against your will? }\end{array}$ \\
\cline { 2 - 3 } & Yes & No \\
\hline Yes & $46(67.6 \%)^{*}$ & $22(32.4 \%)$ \\
No & $22(50 \%)$ & $22(50 \%)$ \\
\hline
\end{tabular}

${ }^{*}\left(x^{2}=3.48, \mathrm{df} 112 / 1, p=.05\right)$.

month drug use. According to these authors, the majority of revictimization models focus on how post-traumatic sequelae associated with sexual abuse influence psychological, cognitive, and interpersonal functioning, thereby increasing the risk of revictimization. In this study, $78.7 \%$ of the participants reported sexual abuse revictimization. This figure is higher to the figure of $38 \%$ reported by Walsh, DiLillo, and Scalora [23] in a study of female inmates. Childhood abuse also has a negative impact on the development of the capacity to regulate the emotions, while difficulty using emotional regulation increases a person's vulnerability to psychological disorders. In this study, 82.17\% of participants reported physical abuse revictimization. Victimized women are often afraid of being newly victimized during the process of seeking help [24].

One of the limitations of this study is the lack of a control group of female inmates who were not substance abusers. This type of control would be required to determine whether the level of violence experienced by substance abusers was greater than that of the rest of the population. However, having a control group with a doubly vulnerable population in a marginalized situation of social exclusion would pose an ethical dilemma, since undertaking research with a group of women who do not receive any benefit in exchange for their participation could be regarded as an abuse of power.

In the case of women in prison, penitentiary policies and administration should encourage the implementation of social readaptation and reinsertion programs, by reducing marginalization and providing treatment. The majorities of female prisoners belong to less privileged social classes and have limited cultural knowledge, in addition to problems of substance abuse and, as shown in the study, various experiences of traumatic violence. Investment in treatment in these areas during the prison sentence and after release may contribute to preventing these women from become repeat offenders. Creating sources of work and halfway houses that continue the program to prevent relapses into substance use, which foster self-care habits and provide reproductive health programs and specialized treatment for trauma and violence, can help defend the human rights of this group of women and achieve social justice.
Competing interests

The authors declare that they have no competing interests.

\section{Authors' contributions}

BM is the general director of Monte Fénix Clinic and supervised work in the penitentiary system. She made substantial contributions to the study's conception and design. PZ made substantial contributions to the acquisition of data. MR drafted the manuscript and critically revised the article's content. GS was in charge of the statistical analysis of data. All authors read and approved the final manuscript.

\section{Authors' information}

BM Addiction specialist. She is the general director of Monte Fénix Clinic and has been in charge of addiction treatment supervision for the past 20 years. She designed the prison program for women inmates to contribute to crime prevention and inmates' drug rehabilitation.

PZ Addiction specialist. She was the director of the Higher Education Center of Monte Fénix when the research was conducted. She was in charge of the addiction specialization studies for training health professionals.

MR holds an MD in clinical psychology and a PhD in anthropology. She is a medical science researcher at the National Institute of Psychiatry and her research interests include women's addiction problems. She is a scientific advisor to Monte Fénix.

GS She holds a PhD in psychology. She is a medical science researcher at the National Institute of Psychiatry and specializes in sexual violence problems.

\section{Acknowledgements}

The authors thank the female inmates for participating in the research project. They are also grateful to Guadalupe Espinosa Rugarcia, president of Monte Fénix's board of trustees, for the financial support provided for research expenses and publishing.

Thanks are due to the General directorate of Santa Martha Acatitla Prison for providing the logistic support for making the inmates' treatment possible.

\section{Author details}

${ }^{1}$ Monte Fénix. Las Flores 439. San Angel Inn. Delegación Alvaro, Delegación Alvaro Obregón 01060, D. F, México. ${ }^{2}$ Instituto Nacional de Psiquiatría Ramón de la Fuente Muñiz, Camino a Xochimilco 101. San Lorenzo Huipulco,

Tlalpan 14370, D. F, México.

Received: 15 April 2014 Accepted: 21 January 2015

Published: 9 February 2015

\section{References}

1. Messina N, Grella C. Childhood trauma and women's health outcomes in a California prison population. American Journal of Public Health. 2006;96 (10):1842-8.

2. Romero M. Mujeres en prisión: una mirada a su salud menta. Mexico: Ed. Liberaddictus; 2004.

3. Romero M, Durand A. Mujeres, prisión y drogas. In: Instituto Nacional de Psiquiatría y Fundación Gonzalo Río Arronte, editor. Intervencion desde la perspectiva de género y la reducción del daño. Mexico: 2007.

4. Colmenares-Bermúdez E, Romero-Mendoza MP, Rodríguez-Ruíz EM, DurandSmith AL, Saldivar-Hernández GJ. Female depression and substance dependence in the México City penitentiary system. Salud Mental. 2007;30:53-61.

5. Pulido-Criollo F, Rodriguez-Landa JF, Colorado-Martinez MP. Factores sociodemográficos asociados con los síntomas depresivos en una muestra de mujeres recluidas en dos prisiones de México. Revista Panamericana de Salud Pública. 2009;26(3):209-15.

6. Huntington N, Moses DJ, Veysey B. Developing and implementing a comprehensive approach to serving women with co-occurring disorders and histories of trauma. Journal of community psychology. 2005:33(4):395-410.

7. SAHMSA. Trauma definition en. 2012. http://www.samhsa.gov.traumajustice/ traumadefinition/definition.aspx Last accessed: 30/08/2013.

8. World Health Organization. Guidelines for the management of conditions specifically related to stress. Geneva: WHO; 2013. p. 267.

9. Stein DJ, Chiu WT, Hwang I, Kessler RC, Sampson N, Alonso J, et al. Crossnational analysis of the associations between traumatic events and suicidal behavior: findings from the WHO World Mental Health Surveys. PLOS One. 2010;5(5):e10574. 
10. Burke C, Martsolf D, Ross R, Benson C, Warner A, Mwemba P. The essence of healing from sexual violence: A qualitative methasynthesis. Research in nursing and health. 2009;32(4):366-78.

11. Wilson DR. Health consequences of childhood sexual abuse. Perspectives in psychiatric care. 2010;46(1):56-64.

12. Segerstrom S, Miller G. Psychological stress and the human immune systema: a metanalytic study of 30 years of inquiry. Psychol Bull. 2004;130 (4):601-30.

13. Meewisee ML, Reitsma J, De Vries G, Gersons B, Olff M. Cortisol and posttraumatic stress disorder in adults: systematic review and meta-analysis. BJP. 2007;191:387-92.

14. Huntington N, Moses DJ, Veysey B. Developing and implementing a comprehensive approach to serving women with co-occurring disorders and histories of trauma. Journal of community psychology. 2005;33(4):395-410.

15. Ullman S, Najdowski C, Filipas H. Child sexual abuse, post-traumatic stress disorder, and substance use: predictors of revictimization in adult sexual assault survivors. Journal of child sexual abuse. 2009;18:367-85.

16. Rivera-Rivera L, Allen B, Chavez-Ayala R, Avila-Burgos L. Abuso físico y sexual durante la niñez y re victimización de las mujeres mexicanas durante la edad adulta. Salud Pública de México. 2006;48(2):268-77.

17. Matthews R. Una propuesta realista de reforma para las prisiones de Lationamerica. Politcrim. 2011;6(12):296-338. http://www.scielo.cl/scielo.php? script=sci_arttex\&pid=S0718-3399201 100020003\&lng=es\&nrm=iso accessed September 20th, 2014.

18. Bergman A, Azaola E. Carceles en Mexico. Cuadros de una crisis. Urvio, revista Lationamericana de seguridad ciudadana. 2007;1(5):74-87.

19. Romero Mendoza M, Saldivar G, Loyola L, Rodríguez E, Galván J. Inequidades de género, abuso de sustancias y barreras al tratamiento en mujeres en prisión. Salud Mental. 2010;33(6):499-506.

20. Briere J. Psychological assessment of adult post-traumatic states, Phenomenology, diagnosis, and measurement. 2nd ed. Washington, D.C American Psychological Association; 2004.

21. Romero M, Bejarano J, Villatoro J, Fleiz C, Saenz M. Violence and abuse in society. In: Brown Miller A, editor. Understanding global crises, vol. Volume 3. 2012. p. 237-54

22. Messman MT, Walsh K, DiLillo D. Emotion dysregulation and risky sexual behavior in revictimization. Child abuse \& Neglect. 2010;34:967-76.

23. Walsh K, DiLillo D, Scalora M. The cumulative impact of sexual revictimization on emotion regulation difficulties. An examination of female inmates Violence against women. 2011;17(8):1103-18.

24. Fearday F, Cape A. A voice for traumatized women: inclusion and mutual support. Psychiatric rehabilitation journal. 2004;27(3):258-65.

doi:10.1186/1747-597X-10-5

Cite this article as: Mejía et al:: Traumatic experiences and re-victimization of female inmates undergoing treatment for substance abuse. Substance Abuse Treatment, Prevention, and Policy 2015 10:5.

\section{Submit your next manuscript to BioMed Central and take full advantage of:}

- Convenient online submission

- Thorough peer review

- No space constraints or color figure charges

- Immediate publication on acceptance

- Inclusion in PubMed, CAS, Scopus and Google Scholar

- Research which is freely available for redistribution 